\title{
Pengaruh Implementasi Kebijakan Rencana Strategis dan Pengawasan Melekat Terhadap Kinerja Petugas Kesehatan Di Rumah Sakit Umum Daerah Kota Bogor Tahun 2015
}

\section{The influence of Implementation Strategic Planning Policy and Monitoring Embedded Toward Health Officer Performance in Bogor District Public Hospital 2015}

\author{
Sari Chandrawati ${ }^{1}$, Agus Nurudin ${ }^{2}$ \\ 1)Dinas Kesehatan Kotamadya Bogor, West Java, Indonesia \\ 2) Program Magister Kesehatan Masyarakat, Fakultas Kedokteran dan Kesehatan, Universitas \\ Muhammadiyah Jakarta, Indonesia \\ Program Magister Kesehatan Masyarakat \\ Fakultas Kedokteran dan Kesehatan, Universitas Muhammadiyah Jakarta. \\ Jl. KH Dahlan, Ciputat Timur, Tangerang Banten,15419. Email: nurudinnew@yahoo.com
}

\begin{abstract}
Abstrak
Latar Belakang :Peningkatan jumlah pasien serta minimnya jumlah tenaga kesehatan yang memiliki sertifikasi kesehatan, menjadikan kinerja petugas kesehatan di Rumah Sakit Umum Daerah (RSUD) Kota Bogor menjadi belum sepenuhnya optimal. Peneliti akan memfokuskan penelitian pada aspek implementasi terhadap kebijakan rencana strategis dan Pengawasan Melekat terhadap Kinerja Petugas Kesehatan pada RSUD Kota Bogor.

Metode :Metode penelitian kuantitatif dengan analisis Structural Equation Modeling (SEM), untuk mengetahui sejauhmana pengaruh dari kedua variabel implementasi kebijakan dan pengawasan melekat (variabel bebas) terhadap variabel kinerja (terikat). Responden merupakan petugas kesehatan RSUD Kota Bogor. Penelitian ini dilakukan dengan membagikan angket untuk mendapatkan pendapat dari tenaga kesehatan. Penentuan responden berdasarkan rumus di Tabel Krejcie dalam Sugiono dengan margin kesalahan 5\%, dengan kontribusi yang proporsional dari masing-masing profesi tenaga kesehatan yang ada di RSUD Kota Bogor. Adapun profesi tenaga kesehatan dan jumlah proporsional sampel yang ditentukan di RSUD Kota Bogor meliputi Petugas Kesehatan Tenaga Medis 41 responden, Petugas Kesehatan Tenaga Keperawatan 141 responden, Petugas Kesehatan Tenaga Kefarmasian 17 responden, Petugas Kesehatan Tenaga Kesehatan Masyarakat 8 responden, Petugas Kesehatan Tenaga Gizi 1 dan Petugas Kesehatan Tenaga Keteknisian Medis 19 responden. Responden merupakan pegawai tetap di RSUD Kota Bogoryang mempunyai masa kerja minimal 1 tahun.
\end{abstract}

Hasil : Dari 200 responden didapatkan hasil koefisien pengaruh implementasi kebijakan terhadap kinerja petugas kesehatan sebesar 65\%, dan koefisien pengaruh pengawasan melekat terhadap kinerja petugas kesehatan sebesar 58\%. Jika dilihat dari uji-t maka t hitung variabel implementasi kebijakan menunjukkan hasil $11,11>\mathrm{t}$ tabel $(1,96)$ dan $\mathrm{t}$ hitung variabel Pengawasan melekat menunjukkan hasil 10,93> t tabel $(1,96)$ sehingga bisa dinyatakan bahwa kedua variabel berpengaruh secara signifikan terhadap kinerja petugas kesehatan RSUD Kota Bogor.

Simpulan : Terdapat hubungan yang signifikan dengan koefisien yang kuat antara pengaruh implementasi kebijakan perencanaan strategis terhadap kinerja petugas kesehatan RSUD Kota Bogor dan juga terdapat hubungan yang signifikan dengan koefisien yang kuat antara pengaruh pengawasan melekat terhadap kinerja petugas kesehatan di RSUD Kota Bogor

Kata kunci:Implementasi Kebijakan Perencanaan Strategis, Pengawasan Melekat dan Kinerja 


\begin{abstract}
Background:The incremental number of patient and the minimum level of medical officer having sertification impact to un optimum level of performance among the medical officers in Bogor District of Public Hospital (RSUD Kota Bogor). Researchers focus to have a research on the aspect of the implementation of strategic planning policy and monitoring embedded toward performance of medical officer in RSUD Kota Bogor
\end{abstract}

Metode :The research is conducted to use quantitative method withStructural Equation Modeling (SEM) analitic to know on the influence level of two variables, implentation of strategic planning policy and monitoring embed as latent varible eksogen toward the performance of medical officer as latent variable endogen.Total sample is 200 respondent out of 377 total population of medical officer in RSUD Kota Bogor. Number of respondent is set base on KrejcieTable with margin of error $5 \%$ plus $10 \%$ reserve. The respondent cover proportionality of all the profession in RSUD Kota Bogor with the detail proportion as follow : Medical 41 responden, Nurse 141 responden,Pharmacy Kefarmasian 17 responden,Public health officer 8 responden, Nutritionist 1 and Technical Medic 19 responden. Responden is permanent employee with year of service minimum 1 year in RSUD Kota Bogor.

Hasil : The coefficient of implementation on strategic planning policy toward performance of medical officer reached 65 percent (0.65) while coefficient of monitoring embedded toward performance medical officer reached 58 percent (0.58). Base on T-test, the results show t result of implementation on strategic planning policy $11,11>\mathrm{t}$ table $(1,96)$ and $\mathrm{t}$ result of variabel monitoring embedded 10,93 $>\mathrm{t}$ table $(1,96)$ therefore it can be concluded that both eksogen variables have significantly influence toward the performance of medical officer in RSUD Kota Bogor.

Simpulan : There is a significant correlation with strong coefficient $(0,65)$ the influence of implementation strategic planning policy toward medical officer performance in RSUD Kota Bogor and there is also a significant correlation with strong coefficient $(0,58)$ the influence of monitoring embedded toward the performance of medical officers in RSUD Kota Bogor

Kata kunci:Implementation on Policy of Strategic Planning, Embedded Monitoring and Performance 


\section{PENDAHULUAN}

Pelayanan kesehatan yang prima dan professional merupakan tuntutan dasar masyarakat.Sumber daya manusia (SDM) yang professional, teknologi kesehatan dan fasilitas pelayanan kesehatan yang optimal dan modern sangat dibutuhkan untuk memenuhi tuntutan tersebut.Tantangan bagi manajemen rumah sakit memerlukan pendekatan solusi dengan menyeluruh dan terpadu.Untuk itu diperlukan biaya yang tidak murah dan sangat disadari oleh masyarakat sebagai penerima jasa layanan. Bagi masyarakat harapan akan kesembuhan dan pelayanan yang baik lebih bernilai.

Kinerja rumah sakit di hadapan publik juga menjadi fokus bagi manajemen rumah sakit yang memerlukan solusi dengan konsep pemikiran yang strategis dan suatu pola pendekatan yang menyeluruh dan terpadu.Rumah sakit umum daerah untuk peningkatan kinerja tidak hanya cukup mencakup perubahan atau penyesuaian konsep pelayanan kesehatan yang lebih meluas, tetapi juga mencakup suatu kebijakan dan strategi peningkatan kepercayaan dan antusias masyarakat yang berada di Kota Bogor khususnya.Peningkatan kinerja petugas kesehatan pada RSUD Kota Bogor merupakan salah satu pilihan strategi untuk meningkatkan produktivitas, efektivitas dan efisiensi bisnis pelayanan kesehatan.RSUD Kota Bogor mempunyai 377 tenaga kesehatan dengan 38\% sudah tersertifikasi dan $62 \%$ belum bersertifikat (RSUD Kota Bogor, 2015) ${ }^{1}$. Hal ini menunjukkan adanya peluang perbaikan dari segi aspek pengelolaan karyawan serta kebijakan strategi rumah sakit yang terkait serta tuntutan dalam memberikan arahan, bimbingan serta pengawasan untuk memajukan rumah sakit.

Dilihat dari jumlah kunjungan pasien sejak berdirinya RSUD Kota Bogor setelah masuk era BPJS menunjukkan peningkatan yang sangat pesat. Pada September 2014 total kunjungan pasien 19.152 dan pada bulan Desember 2014 sudah mencapai 35.490 kunjungan pasien (RSUD Kota Bogor 2015) ${ }^{1}$. Peningkatan jumlah pasien yang tinggi dan peningkatan kualifikasi tenaga kesehatan yang tidak sejalan menuntut kemampuan manajemen rumah sakit untuk berpikir strategis dan melakukan pengawasan operasional yang lebih ketat bagi tercapainya kinerja rumah sakit sesuai dengan tuntutan pelayanan dan pengobatan secara maksimal.

Penelitian ini bertujuan untuk mengetahui seberapa besar pengaruh Implementasi Kebijakan Rencana Strategis terhadap Kinerja Petugas Kesehatan pada RSUD Kota Bogor dan mengetahui seberapa besar pengaruh Pengawasan Melekat terhadap Kinerja Petugas Kesehatan pada RSUD Kota Bogor.

\section{METODE PENELITIAN}

Metode Penilitian dilakukan dengan metode kuantitatif dengan analisa Structural Equation Modeling (SEM) dan menggunakan Software LISREL (Linear Structural Relationships). Penelitian ini dilakukan di bulan Juli-September 2015 di RS Umum Daerah Kota Bogor dengan alamat lokasi beralamat di J1, Dr Sumeru No. 120 Kelurahan Menteng, Kecamatan Bogor Barat, Kota Bogor Kode Pos 16111, Telp. (0251) 8312292 Fax.(0251) 8371001. Pengambilan sampel secara proportional stratified random 
sampling dengan jumlah sampel menurut Tabel Krejcie dalam Sugiono (2002) ${ }^{2}$ adalah 200 responden (182 sampel ditambah 10\% tambahan) dari total populasi rata-rata 377 $(\alpha=5 \%)$. Pengambilan proporsionalitas dilakukan berdasarkan pada pembagian masing-masing profesi yang ada di RS Umum Daerah Kota Bogor yang meliputi Petugas Kesehatan Tenaga Medis 41, Petugas Kesehatan Tenaga Keperawatan 114, Petugas Kesehatan Tenaga Kefarmasian 17, Petugas Kesehatan Tenaga Kesehatan Kemasyarakatan 8, Petugas Kesehatan Tenaga Gizi 1, Tenaga Keteknisian Medis 19.

Penelitian dilakukan dengan pengisian kuesioner yang terdiri atas 67 pertanyaan dengan menggunakan skala ukur Likert. Dalam penggunaan SEM setiap variabel laten biasanya mempunyai beberapa ukuran atau variabel teramati atau indicator (Wijanto, 2007:10) ${ }^{3}$ Penggunaan SEM akan menghubungkan variabel laten dengan variabel-variabel teramati melalui model pengukuran yang berbentuk analisis faktor dan banyak digunakan di psikometri dan sosiometri.

Dalam penelitian ini dilakukan $\mathrm{Uji}$ Kecocokan maka dilakukan dengan menilai GOF (Goodness of Fit).Uji kecocokan antara data dengan model, validitas dan reliabilitas model pengukuran, dan signifikansi koefisien model struktural.

Menurut Igbarian yang menggunakan guidelines dari Hair dalam Wijanto, 2008: 6533, tentang relative importance and significant of the factor loading of each item. Menyatakan bahwa muatan faktor standar (standardized loading factors) $\geq 0,50$ adalah very significant.
Untuk evaluasi terhadap reliabilitas (reliability) dari model pengukuran adalah konsistensi suatu pengukuran. Secara umum untuk mengestimasi reliabilitas adalah test retest, alternative form, split-balvesdan Cronbach's Alpha. Berdasarkan hal tersebut untuk mengukur reliabilitas dalam SEM akan digunakan composit reliability measure (ukuran reliabilitas komposit) dan variance extracted measure (ukuran ekstrak varian). Sebuah konstruk dinyatakan baik jika mempunyai reliabilitas adalah sebagai berikut:

a. Nilai Construct Reliability (CR)-nya $\geq 0,70$

b. Nilai Variance Extracted (VE)-nya $\geq 0,50$

\section{HASIL PENELITIAN}

\subsection{Profile Rumah Saklit Umum Daerah Kota Bogor}

RSUD Kota Bogor didirikan tahun 1980 diatas tanah milik Pemerintah Daerah seluas 5 hektar (5 ha) di daerah Cilendek Kelurahan Menteng Kecamatan Bogor Barat, berdiri bangunan satu lantai seluas $990 \mathrm{~m}^{2}$ yang direncanakan sebagai unit Gawat Darurat.Kerjasama antara Pihak Yayasan Karya Bhakti dengan Pemerintah Daerah Kota Bogor.Pada 7 Agustus 2014 lalu Walikota Bogor meresmikan RSUD Kota Bogor yang semula bernama RS. Karya Bhakti. Dengan diresmikannya RSUD Kota Bogor yang semula pengelolaan manajemen swasta menjadi RSUD Kota Bogor dibawah naungan Pemerintah Kota Bogor. RSUD Kota Bogor berdiri di lahan $30.000 \mathrm{M}^{2}$ dengan luas bangunan seluas 7.924 $\mathrm{M}^{2}$ beralamat di Jl. Dr. Semeru 120 Kota Bogor dipimpin oleh seorang Direktur dan kategori RS Tipe B non pendidikan, dengan standar 
pelayanan yang bersertifikat dari Kementerian Kesehatan Republik Indonesia Akreditasi Rumah Sakit No. HK.00.06.3.5.2605 yaitu dengan status pelayanan Penuh Tingkat Lanjut (12 Pelayanan), serta dengan Pola Pengelolaan Keuangan PPK-BLUD Penuh No. 900.45-144 tahun 2014.Jumlah tempat tidur yang tersedia adalah sebanyak 202 tempat tidur.

Karakteristik sumber daya manusia di RSUD Kota Bogor yang akan dijadikan sebagai responden dalam penelitian ini meliputi pendidikan, status sosial dan usia (Profil RSUD Kota Bogor, 2015) ${ }^{64}$

1. Tingkat Pendidikan SLTA $2 \%$, Diploma $72 \%$, Sarjana $11 \%$ dan Magister 15\%

2. Status perkawinan $81 \%$ menikah dan $16 \%$ belum menikah

3. Kelompok Usia, 21-25 tahun 11\%, 26-30 tahun 44\%, 31-40 tahun 25\%, 41-50 tahun $14 \%$ dan diatas 50 tahun $6 \%$

\subsection{Hasil Pengujian}

\subsubsection{Hasil Uji Kecocokan Model}

Hasil analisis Goodness of Fit model yang tersaji di Tabel Hasil Uji Kecocokan Model dapat dijelaskan dari Statistik Chi - Square, Goodness of Fit dan Adjusted Goodness of Fit menunjukkan model tidak fit dengan data, tetapi Root Mean Square Error of Approximation (RMSEA), Comparative Fit Index (CFI), Normed Fit Index (NFI), dan Incremental Fit Index (IFI) maka model dapat diasumsikan dapat diterima karena telah mengindikasikan "reasonable error of approximation". Hasil analisis terhadap kecocokan ini secara keseluruhan model adalah baik. (Wijanto, 2008:186)3. CFI, dan NFImenunjukkan bahwa "estimated population covariance matrix" konsisten dengan matrik kovarian yang dihasilkan oleh data sampel. Untuk itu, model penelitian bisa diterima, sehingga model penelitian bias dijalankan.Padamodel persamaan diatas maka dapat dilakukan persamaan structural :

1. Persamaan Struktural $\xi_{1}$ terhadap $\eta=\gamma_{1} \xi_{1+}$

$$
\zeta_{1}=0,65 \xi_{1}+0,35
$$

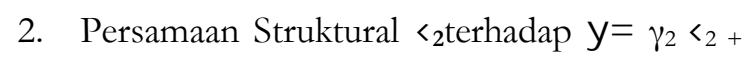
$\zeta_{2}=0,58 \xi_{2}+0,42$

\subsubsection{Uji Validitas}

Hasil pengujian validitas variable eksogen implementasi kebijakan perencaan strategis menunjukkan seluruh variable dinyatakan valid dengan nilai loading memiliki korelasi yang kuat terhadap konstruk yang mendasarinyakarena nilai validitas lebih besar dari kriteria penguji yaitu 0,60.

Variabel Pengawasan Melekat diukur melalui 22variabel manifes dan hasilnya menunjukkan bahwa nilai loading memiliki korelasi yang kuat terhadap konstruk yang mendasarinyakarena nilai validitas lebih besar dari kriteria penguji yaitu 0,60.

Variabel Kinerja Petugas Kesehatan diukur melalui 18 variabel manifes. Nilai loading memiliki korelasi yang kuat terhadap konstruk yang mendasarinyakarena nilai validitas lebih besar dari kriteria penguji yaitu 0,60 .

Hasil pengujian validitas terhadap ketiga variable manifes memiliki hubungan yang kuat dengan konstruk, jadi konstruk dinyatakan valid.

\subsubsection{Pengujian Reliabilitas}


Pengujian reliabilitas dilakukan, untuk menunjukkan sejauh mana suatu alat ukur yang dapat memberikan hasil yang relatif sama apabila dilakukan pengukuran kembali pada obyek yang sama. Pengujian tersebut dapat dilakukan dengan melihat nilai Composite Reliability (CR) dan nilai AverageAverage variance extracted (AVE). Berdasarkan hasil pengolahan terhadap variable implementasi kebijakan perencanaan strategis dapat dilihat pada CR sebesar 0,98 $\geq 0,70$, dan AVE sebesar $0,68 \geq 0,50$, sehingga bias dinyatakan mempunyai tingkat konsistensi yang baik.

Tabel. Uji Kecocokan Model

\begin{tabular}{|c|c|c|c|}
\hline $\begin{array}{r}\text { Indikator } \\
\text { Goodness offit }\end{array}$ & Nilai & Kriteria & $\begin{array}{c}\text { Ketera } \\
\text { ngan }\end{array}$ \\
\hline Degree of Freedom & 2141 & & \multirow{3}{*}{$\begin{array}{l}\text { Model } \\
\text { tidak } \\
\text { fit }\end{array}$} \\
\hline \multirow{2}{*}{ Chi-Square (p) } & 2537.19 & & \\
\hline & $(p=0,000)$ & $\mathrm{p}>0,05$ & \\
\hline $\begin{array}{l}\text { Root Mean Square } \\
\text { Error of } \\
\text { Approximation } \\
\text { (RMSEA) }\end{array}$ & 0,03 & $<0,08$ & $\begin{array}{l}\text { Model } \\
\text { fit }\end{array}$ \\
\hline $\begin{array}{l}\begin{array}{l}\text { Normed } \\
\text { Fit }\end{array} \text { Index } \\
(\mathrm{NFI})\end{array}$ & 0,97 & $>0,90$ & $\begin{array}{l}\text { Model } \\
\text { fit }\end{array}$ \\
\hline $\begin{array}{ll}\text { Non-Normed } & \text { Fit } \\
\text { Index (NNFI) } & \end{array}$ & 0,99 & $>0,90$ & $\begin{array}{l}\text { Model } \\
\text { fit }\end{array}$ \\
\hline $\begin{array}{ll}\text { Comparative } & \text { Fit } \\
\text { Index }(\mathrm{CFI}) & \end{array}$ & 0,99 & $>0,90$ & $\begin{array}{l}\text { Model } \\
\text { fit }\end{array}$ \\
\hline $\begin{array}{l}\text { Incremental } \\
\text { Index (IFI) }\end{array}$ & 0,99 & $>0,90$ & $\begin{array}{l}\text { Model } \\
\text { fit }\end{array}$ \\
\hline $\begin{array}{l}\begin{array}{l}\text { Relative } \\
\text { (RFI) }\end{array} \\
\text { Fit }\end{array}$ & 0,96 & $>0,90$ & $\begin{array}{l}\text { Model } \\
\text { fit }\end{array}$ \\
\hline $\begin{array}{l}\text { Goodness of Fit } \\
\text { Index (GFI) }\end{array}$ & 0,72 & $>0,90$ & $\begin{array}{l}\text { Model } \\
\text { tidak } \\
\text { fit }\end{array}$ \\
\hline $\begin{array}{l}\text { Adjusted Goodness } \\
\text { of Fit Index (AGFI) }\end{array}$ & 0,71 & $>0,90$ & $\begin{array}{l}\text { Model } \\
\text { tidak } \\
\text { fit }\end{array}$ \\
\hline
\end{tabular}

Hasil pengolahan data pada variabel pengawasan melekat denganCR variabel Pengawasan Melekat yaitu $0,98 \geq 0,70$ dan nilai AVE yang diperoleh sebesar $0,67 \geq 0,50$ yang menunjukkan variabel manifest pada variabel pengawasan melekat dapat disimpulkan valid dan reliabel.

Hasil pengolahan data pada variabel kinerja petugas kesehatan dannilai CR sebesar 0,97 $\geq 0,70$ dan nilai AVE adalah sebesar 0,60 $\geq 0,50$, sehingga nilai variabel manifes yang terstruktur dengan variabel kinerja petugas kesehatan dapat disimpulkan bahwa semua variabel manifes valid dan reliabel baik pada level variabel laten.

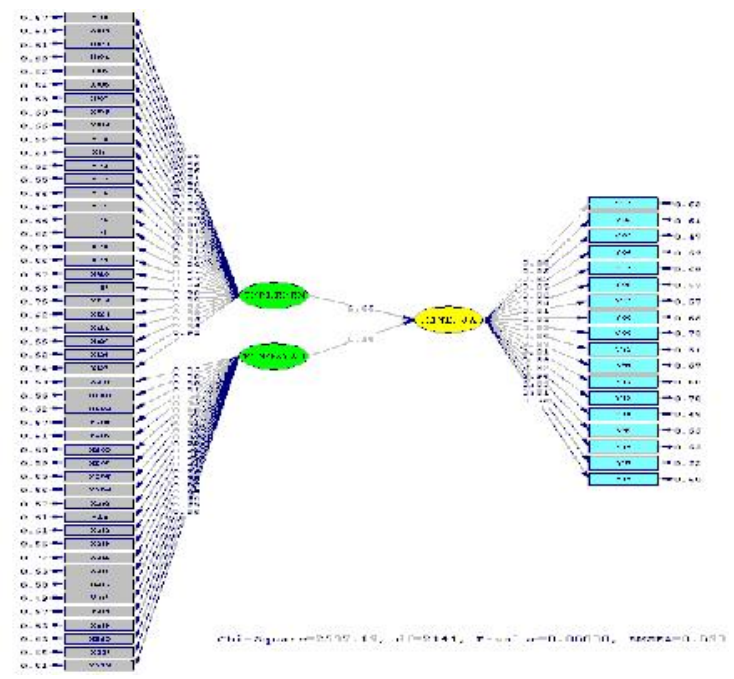

Gambar 5.Hybrid Model SEM Analysis

\subsubsection{Pengujian Hipotesis}

Pengujian model dilakukan untuk mengetahui hasil uji hipotesis penelitian yaitu: (1) Pengaruh Implementasi Kebijakan terhadap Kinerja Petugas Kesehatan Pada Rumah Sakit Umum Daerah Kota Bogor; dan (2) Pengaruh Pengawasan Melekat terhadap Kinerja Petugas 
Kesehatan Pada Rumah Sakit Umum Daerah Kota Bogor.

Hasil uji hipotesis terlihat pada hubungan yang signifikan dengan nilai t-value harus lebih besar dari pada t-tabel (1.96) dengan tingkat kepercayaan 95\%.

H0 : $\Sigma=\Sigma(\theta)$; Kriteria penolakan danpenerimaan hipotesis :

1) Tolak Hipotesis Nol jika t-value $<1,96$

2) Terima Hipotesis Nol jika t-value $>1,96$

\section{Pengujian Hipotesis Pertama dan Pembahasan :}

$\mathrm{H}_{0}$ :Besarnya pengaruh Implementasi Kebijakan Rencana Strategis RSUD Kota Bogor terhadap Kinerja Petugas Kesehatan RSUD Kota Bogor ditentukan oleh variabel-variabel teramati.

Persamaan Struktural T-Values11.11 > 1.96 (t-tabel) jadi pengaruh variabel laten eksogen atau unobserved variabel Implementasi Kebijakan terhadap variabel laten endogen Kinerja Petugas Kesehatan atau unobserved variable kinerja petugas kesehatan melalui masing-masing variabel manivest adalah signifikan. Hasil modelpersamaanstruktural pengaruh diantara variabel laten eksogen terhadap variabel laten endogen dapat dijelaskan pengaruh variabel Implementasi Kebijakan terhadap Kinerja Petugas Kesehatan yang diperoleh sebesar 0,65. Artinya adalah bahwa semua keragaman Kinerja Petugas Kesehatan dapat dijabarkan oleh keragaman Implementasi Kebijakan Rencana Strategis RSUD Kota Bogor yang terpantau dari semua variabel manifest pada penelitian ini.
Rencana Strategis RSUD Kota Bogor Tahun 2015-2019, merupakan suatu acuan bagi para pimpinan, pegawai dan semua perangkat yang terkait dengan RSUD Kota Bogor untuk selalu melakukan kegiatan sesuai dengan kebijakan yang tertuang di dalam penyusunan Rencana Strategis tersebut. Peningkatan kinerja petugas kesehatan di RSUD Kota Bogor dapat dilakukan dengan mengimplementasikan segala kebijakan yang tercakup pada Rencana Strategis RSUD Kota Bogor.

Hasil pengukuran dan hipotesis pertama bahwa Implementasi Kebijakan Rencana Strategis berpengaruh signifikan terhadap Kinerja Petugas Kesehatan di RSUD Kota Bogor.Hubungan ini bermakna bahwa apabila Implementasi Kebijakan Rencana Strategis ditingkatkan atau meningkat penerapannya maka peningkatan tersebut secara stimulan diikuti dengan peningkatan Kinerja Petugas Kesehatan di RSUD Kota Bogor.

Berdasarkan landasan teori implementasi kebijakan publik Van Meter dan Van Horn (2002 : 45) dalam Hill (2002) ${ }^{4}$ maka variabel Implementasi Kebijakan Rencana Strategis dipandang sebagai pelaksanaan ketentuan tentang rencana strategis yang dinyatakan dengan kebijakan standar dan tujuan, sumber daya dan insentif, kualitas hubungan antar organisasi, karakteristik lembaga implementasi, lingkungan ekonomi, sosial dan politik, dan respon pelaksana kebijakan.

Berdasarkan analisa dapat dinyatakan bahwa besarnya pengaruh Implementasi Kebijakan Rencana Strategis terhadap Kinerja 
Petugas Kesehatan RSUD Kota Bogor ditentukan oleh 27 variabel manifes

Berdasarkan analisa di dapatkan juga nilai tertinggi pada pemberian reward atau insentif kepada petugas yang merupakan bagian dari dimensi sumber daya dan insentif dan merupakan hal yang harus diprioritaskan untuk dijalankan dan dikembangkan guna meningkatkan kinerja petugas kesehatan di RSUD kota Bogor. Adapun faktor yang dimaksud adalah prestasi dan respon tenaga kesehatan terhadap kendala lingkungan.

Merujuk pada hasil dari analisa statistik prestasi adalah merupakan faktor yang dominan dalam meningkatkan kinerja petugas kesehatan di RSUD Kota Bogor, prestasi yang dimaksud adalah dengan melaksanakan tugas dan fungsi sebagai petugas kesehatan dengan sebaik-baiknya dan melayani pasien/keluarga pasien dengan sepenuh hati, serta dengan mentaati segala bentuk peraturan yang berlaku baik secara internal di RSUD Kota Bogor maupun peraturan yang menyangkut tentang pelayanan publik di bidang kesehatan sesuai dengan perudangundangan yang berlaku. Insentif ataupun penghargaan terhadap prestasi bias dilakukan dalam bentuk finansial atau dapat pula diberikan dalam bentuk barang. (Nawawi, 1999: 316) ${ }^{5}$

Hasil penelitian ini sejalan dengan dari hasil penelitian Wibowo $(2007)^{6}$ pada Sekretariat Daerah Kota Bogor yang menjelaskan bahwa terdapat pengaruh Implemntasi Kebijakan terhadap Kinerja Pegawai dan sekaligus hasil penelitian yang disampaikan Wijanto (2008: 10)3.

Van Meter and Van Horn's dalam Hill and Hupe (2002:46) ${ }^{4}$ menjelaskan juga keberhasilan dari tahapan pelaksanaan kebijakan strategis dalam meningkatkan kinerja. Gordon $(1993: 14)^{7}$ menjelaskan hal yang sejalan yaitu implementasi kebijakan yang dilakukan dengan pengawasan diukur dalam bentuk kinerja (performance).Sedangkan Dessler $\quad(2008: 12)^{8}$ keberhasilan dilakukan dg cakupan yang meliputi: (1) penetapan standar kinerja, (2) penilaian kinerja aktual karyawan dalam hubungan dengan standar, (3) memberi umpan balik kepada karyawan dengan tujuan memotivasi yang bersangkutan untuk menghilangkan kemerosotan kinerja.

\section{Pengujian Hipotesis Kedua}

$\mathrm{H}_{0} \quad$ : Besarnya pengaruh Pengawasan Melekat terhadap Kinerja Petugas Kesehatan di RSUD Kota Bogor ditentukan oleh variabelvariabel teramati.

Berdasarkan hasil pengukuran tingkat signifikansi, dapat disimpulkan bahwa model persamaan struktural menunjukkan nilai t-value lebih besar dari kriteria dalam analisis SEM yaitu 10,93 (nilai t-value $\geq 1,96$ ) sehingga dapat dinyatakan bahwa hipotesis terbukti secara signifikan bahwa Pengawasan Melekat berpengaruh terhadap Kinerja Petugas.

Hasil modelpersamaanstruktural pengaruh diantara variabel laten eksogen terhadap variabel laten endogen dapat dijelaskan bahwa hasil model persamaan struktural pengaruh variabel Pengawasan Melekat terhadap Kinerja Petugas Kesehatan yang diperoleh sebesar 0,58 .

Salah satu unsur dalam pengelolaan sebuah organisasi adalah dengan adanya kontrol atau pengawasan dari setiap kegiatan organisasi, 
sehingga dengan adanya kontrol atau pengawasan diharapkan proses yang sedang berjalan di organisasi tersebut telah sesuai dengan tujuan yang telah direncanakan sebelumnya.

RSUD Kota Bogor dengan adanya perubahan status dari Rumah sakit swasta menjadi Rumah Sakit milik pemerintah memerlukan pengawasan lebih baik lagi ataupun pengawasan tersebut lebih melekat serta lebih intensif, sehingga dengan pengawasan melekat ini dapat meningkatkan kinerja dari petugas kesehatan di RSUD Kota Bogor.

Berdasarkan hasil pengukuran dan pengolahan hipotesis kedua bahwa Pengawasan Melekat berpengaruh signifikan terhadap Kinerja Petugas Kesehatan di RSUD Kota Bogor.Adanya pengaruh tersebut menunjukkan bahwa di Pengawasan Melekat yang diposisikan sebagai variabel konsekuensi terjalin suatu mekanisme hubungan kausalitas. Hubungan ini bermakna bahwa apabila Pengawasan Melekat ditingkatkan atau meningkat penerapannya maka peningkatan tersebut secara stimulan diikuti dengan peningkatan Kinerja Petugas Kesehatan di RSUD Kota BogorOleh sebab itu, Kinerja Petugas Kesehatan dapat ditingkatkan dengan meningkatkan efektivitas Pengawasan Melekat yang dilakukan oleh masing-masing pimpinan unit keja di RSUD Kota Bogor, penerapan Pengawasan Melekat ini menyetuh langsung kepada semua Petugas Kesehatan di RSUD Kota Bogor karena petugas kesehatan yang menyentuh langsung kepada penerapan pelayanan terhadap penerima layanan.
Berdasarkan teori Sujamto (1996:78)9 yang mengatakan bahwa Pengawasan melekat adalah suatu kegiatan yang harus dilaksanakan oleh pemimpin pada RSUD Kota Bogor secara terus menerus atau berkala dalam rangka melakukan pemantauan, pemeriksaan, penilaian dan perbaikan agar bawahan dapat bekerja secara efektif, efisien dan sesuai dengan prosedur yang telah ditetapkan.

Secara stimulan penerapan Pengawasan Melekat yang dilakukan dengan mengaktualisasikan ke-22 indikator penelitian tersebut dapat meningkatkan Kinerja Petugas Kesehatan di RSUD Kota Bogor dalam melaksanakan atau Pengawasan Melekat.Pada analisa didapatkan bahwa pimpinan yang selalu melakukan pemeriksaan ketelitian dan pimpinan yang selalu memotivasi kerja merupakan bagian dari dimensi perbaikan.

Perhitungan statistic menghasilkan bahwa ketelitian dan motivasi yang diberikan oleh seorang pemimpin baik itu pemimpin dari RSUD Kota Bogor maupun pimpinan masingmasing unit kerja dapat meningkatkan kinerja petugas kesehatan. Dengan pemberian motivasi dari pimpinan tersebut dapat meningkatkan gairah bekerja dari petugas kesehatan

Costa dan McCrae (1985) dalam Zubaidah dan Dwijanto $(2013: 27)^{10}$ menjelaskan bahwa ketelitian mendiskripsikan orang-orang yang teratur, terkontrol, terorganisasi, ambisius, terfokus, pada pencapaian, dan memiliki disiplin diri. Secara umum, mereka yang memiliki sifat berhati-hati (conscientiousness) yang tinggi biasanya pekerja keras, berhati-hati, tepat waktu, dan mampu bertahan. 
Ndraha (2000:55) ${ }^{11}$ mengatakan bahwa pemerintahan adalah proses pemenuhan (penyediaan) kebutuhan pihak yang diperintahkan akan jasa publik yang tidak diprivatisasikan dan layanan sipil kepada setiap orang pada saat diperlukan. Untuk memenuhi (menyediakan) layanan sipil tersebut, maka pemerintah sebagai organisasi publik harus menyediakan sejumlah sumber daya (resources) yang memadai, yang salah satu diantaranya adalah tersedianya sumber daya manusia (aparatur) yang profesional, kapabel, dan memiliki motivasi kerja yang optimal.

Menurut Wexley dan Yukl (1992:98) ${ }^{12}$,pengertian motivasi adalah suatu proses dimana perilaku diberikan energi dan diarahkan. Suatu proses hipotetik hanya dapat disimpulkan dengan mengamati perilaku orang, mengukur perubahan dalam pelaksanaan kerjanya, atau memintanya untuk menjelaskan kebutuhanserta tujuan-tujuannya.

Hasil penelitian sejalan dengan hasil penelitian Fahlun (2007) ${ }^{13}$ dengan judul Pengaruh Disiplin Pegawai dan Pengawasan Melekat Terhadap Kinerja Pegawai pada Kantor Kecamatan Pancoran Mas.Dalam penelitian Fahlun menghasilkan bahwa terdapat pengaruh Pengawsan Melekat terhadap Kinerja Pegawai.

\section{KESIMPULAN DAN SARAN}

1. Implementasi Kebijakan Rencana Strategis berpengaruh terhadap Kinerja Petugas Kesehatan dengan tingkat koefisien 0.65

2. Pengawasan Melekat berpengaruh terhadap Kinerja Petugas Kesehatan dengan koefisien 0.58
Intensitas sosialisasi Kebijakan dari Rencana Strategis RSUD Kota Bogor dan rencana implementasi perlu ditingkatkan dan diatur secara regular dan terencana agar setiap individu petugas kesehatan selalu memahami tugas pokok dan fungsi, serta pemahaman yang baik. Perlu dikembangkan kemampuan nilai-nilai Pengawasan Melekat yang dilaksanakan oleh pimpinan RSUD Kota Bogor maupaun pada tiap-tiap unit kerja yang memiliki tanggung secara linear kepada para staf petugas kesehatan.

\section{DAFTAR PUSTAKA}

1. Data Kepegawaian RSUD Kota Bogor 2015

2. Sugiono, 2002. Statistik Untuk Penelitian,Cetakan kedelapan, Bandung: CV. Alfabeta

3. Wijanto, Setyo Hari. 2007. Structural Equation Modeling dengan Lisrel 8.8. Graha Ilmu. Jakarta

4. Hill, Michael and Peter Hupe, 2002. Implementing Publik Policy, London: SAGE Publications Ltd.

5. Nawawi, Hadari, 1999. Manajemen Sumber Daya Manusia Untuk Bisnis yang Komptitif, Gadjah Mada University Press, Yogyakarta

6. Wibowo, Sigit. 2007. Pengaruh Implementasi Kebijakan Anggaran dan Motivasi Pegawai Terbadap Kinerja pada Sekretariat Daerah Kabupaten Bogor. Sekolah Tinggi Ilmu Administrasi Mandala Indonesia. Jakarta

7. Dessler, Garry. (2008). Human Resource management, fourth edition, New Jersey: Prentice Hall Internasional

8. Gordon, J.R, 1993, A Diagnostic Approach To Organizational Behavior, Boston : Allyn and Bacon

9. Sujamto. 1996. Aspek-aspek Pengawasandi Indonesia. Jakarta: Sinar Grafika 
10. Zubaidah, Lilik dan Dwijanto W. Andre, 2013. Pengaruh Faktor Komunikasi, Kepribadian Ekstraversi, dan Kepribadian Ketelitian Terhadap Prestasi Kerja Jurnal Ilmu Manajemen | Volume 1 Nomor 1 Januari 2013.

11. Ndraha. Taliziduhu. 2005. Teori Budaya Organisasi. Jakarta. Rineka Cipta

12. Wexley, Kenneth N dan Gary A. Yulk, 1992 , Perilaku Organisasi Dan Psikologis Personalia, Jakarta : PT. Rineka Cipta.

13. Fahlun. 2007 Pengaruh Disiplin dan Pengawasan Melekat Terhadap Kinerja Pegawai Pada Kantor Kecamatan
PancoranMas Kota Depok. STA Mandala Jakarta

14. Peraturan Walikota Bogor Tahun 2014

15. UU Nomor 23 Tahun 1992 tentang Kesehatan

16. Schermerhorn, J., J. Hunt, \& R. Osborn 1991. Managing Organizational Behavior. 4th. Ed. John Wiley \& Sons 